International Journal of Instruction e-ISSN: 1308-1470 • www.e-iji.net

Article submission code: 20191008083943

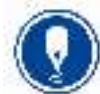

January $2021 \bullet$ Vol.14, No.1

p-ISSN: 1694-609X

pp. 199-214

Received: 08/10/2019

Revision: 14/06/2020
Accepted: 04/07/2020

OnlineFirst:11/10/2020

\title{
Implementation of C-Map Application to Improve Students' Understanding of Work and Energy Matter
}

\author{
Nadi Suprapto \\ Asst. Prof. Dr., Universitas Negeri Surabaya, Physics Education Program, Surabaya, \\ Indonesia,nadisuprapto@unesa.ac.id
}

Didin Nur Cahyani

B.Ed., Universitas Negeri Surabaya, Physics Education Program, Surabaya, Indonesia, didincahyani@gmail.com

\section{Didit Ardianto}

M.Ed., University of Pakuan, Science Education Program, Bogor, Indonesia, diditardianto@unpak.ac.id

\section{Husni Mubarok}

B.Ed., Universitas Negeri Surabaya, Physics Education Program, Surabaya, Indonesia, husnimubarok254@gmail.com
The aims of the study were analyzing students' understanding and skills to make concept mapping in work energy matter through C-Map application software. True experimental method with randomized control group pre-test and post-test design was utilized in the research method. The research involved 72 public high school students from second semester, $10^{\text {th }}$ grade in Indonesia, composed of 36 students in an experiment group (EG) and 36 students in control group (CG). Data were collected by giving a test of work and energy to evaluate students' understanding through C-Map application during Spring Semester 2019. A specific rubric from the previous researchers was used to evaluate students' skills in developing concept map. Analysis of data used independent t-test and normalized gain (N- gain). The independent test revealed the implementation of C-Map application affected in improving students' understanding of work and energy. Students' understanding of these concepts performed that EG higher than CG. It was supported by the obtained of normalized gain (N-gain). The $\mathrm{N}$-gain of EG and CG was 0.39 and 0.26 , respectively. Students' skill to make concept mapping in the topic of work and energy through C-Map application achieved 81.36 of 100 with a very good category. C-Map application guide students to arrange the hierarchical structure concept of work and energy, construct concept from focus question and see how the concept related with another concept.

Keywords: C-Map application, students' understanding, work, energy, skills

Citation: Suprapto, N., Cahvani, D. N., Ardianto, D., \& Mubarok, H. (2021). Implementation of CMap Application to Improve Students' Understanding of Work and Energy Matter. International Journal of Instruction, 14(1), 199-214. https://doi.org/10.29333/iji.2021.14112a 


\section{INTRODUCTION}

The $21^{\text {st }}$ century is a century of knowledge and technology is known as the era of Industrial revolution 4.0 and Society 5.0. This era requires student could perform a specific skill rather than general skill. Four categories of 21st century skill are critical thinking, communication skill, problem solving, creative and innovative collaboration. By implementing some knowledge or concepts into a part of these skills, student can exist in this disruption era. They have able to collaborate their concept, thinking, and skills together to solve some problems. There is a relationship between understanding the concepts and the level of thinking category (Akınoğlu, 2017; Chu, Reynolds, Tavares, Notar, \& Lee, 2017; Suprapto, Chang, \& Ku, 2017). Science learning including physics learning is also dealing with many concepts and thinking skills. Some previous researches indicated that students' understanding of physics concepts are low therefore the thinking skills are also low (Suprapto, Suliyanah, Prahani, Jauhariyah \& Admoko, 2018). Indeed, based on the revised version of Bloom's Taxonomy (Nugroho, Chandra, \& Sanjaya, 2017) revealed that understanding of the concepts a student's level of learning outcomes is not easy way. Students are requested not merely to recall the concept by using their own words. Understanding the concepts is "essential in teaching and learning activities because without concept, the learning process will be hampered" (Nugroho et al., 2017).

A concept map is one of the solutions for facilitating students to evaluate the understanding of their learning (Sarker, 2015). On the other hand, students need to learn and understand to construct a concept map to improve the students' understanding.

According to Novak and Gowin (2012), concept maps have been considered to monitor the changes in students' knowledge in science education. Nugroho et al. (2017) visualized that "the concept of science materials can increase students' interest to science and constructing concept map allow students' grow into active learners". As a learning tool, concept map has a positive impact on the value of students' learning (Lestari, Suprapto, Deta, \& Yantidewi, 2018).

One utilization of information technology that contributes to preparing $21^{\text {st }}$ century learning and C-Map application can improve students' understanding. C-Map application is software initiated by "the Institute for Human Machine Cognition (IHMC)" that contributes to information technology that focuses on creating concept maps in the learning process (Suprapto et al., 2018). According to their research, "creating a concept map can be facilitated through manually via paper and pencil or utilized software".

Based on previous-research was piloted in one of senior high school in natural science groups showed that students never made concept map through application in physics learning and students not yet know an application that it used to create a concept map. Specifically, in work and energy concept, students' understanding is low, $87.7 \%$ of students' have misunderstanding in these concepts (Sukma, Supriyono Koes, \& Kusairi, 2016). 


\section{Context and Literature Review Concept Map}

According to Gourlay (2017), several ways can be used to determine the level of understanding of students about a material, one of which is using concept maps. Research on human learning and knowledge construction by Novak and Gowin (2012) initiated the idea of concept maps. Joseph Novak have already designed and offered a new tool that might be used to grasp the way individuals form the concepts cognitively for the comprehending of some objects. Novak (2012) developed "the concept maps from diagrams indicating a relationship between concepts or between words that are used to represent other concepts" (Usta \& Ültay, 2016). The concept maps are "structures that present the most general concepts down to specific ones; they are used with the purpose of organizing and sequencing content hierarchically concept maps are visual presentations of the connection of a concept and organizational hierarchy" (Santrock, 2014).

According to Novak in Coutinho (2014), concept maps were made to find out knowledge and changes in concepts that have been learned based on the relationships between concepts found by students. Novak and Gowin said in Gourlay (2017) through concept maps teachers can identify or know what students have known. Novak's idea based on Ausubel's learning theory. Through the concept map, the cognitive psychology through the assimilation and accommodation of new concepts into existing concepts could be raised among students; this is the essence of meaningful learning. Coutinho (2014) have also cited the expression of David Ausubel who said that "to be meaningful learning is necessary to establish a relationship between the theme and concept that will be learned from the cognitive structure of the individual".

Novak and Gowin in Gourlay (2017) said that concept maps have been developed to present students' cognitive knowledge. According to White and Gunstone in Gourlay (2017) concept maps can be an indicator to determine the learning quality of students. Concept map is one of the ways that can facilitate students in compiling a hierarchy in a concept (Suprapto et al., 2018). Through the use of concept maps students can represent visually how they believe concepts that are interrelated or related to one another in a subject matter. It also helps teachers to understand how students develop concepts and help teachers if there is an error in understanding a concept or a misconception occurs in the material for students. According to Dahar in Nugroho et al. (2017), the purpose of the use of concept maps is to examine the behavior of students, investigate the existence of misconceptions in material and as an assessment tool for students' understanding. Yamin in Nugroho et al. (2017) have also said that concept maps have several characteristics. Among them, concept maps are representations of students' thinking, concept maps show the relationship between various concepts and some concepts have a hierarchy.

\section{C-Map Application}

Creating concept maps can be facilitated through manually via paper and pencil or utilized an emerging technology (Suprapto et al., 2018). C-Map application software was initiated by "the Institute for Human Machine Cognition (IHMC)" which 
contributes in technology and information in the learning process by focusing on concept mapping. According to Cañas et al. (2004), a C-Map tool was intended based on a modern technology in learning, in which components can be inserted or replaced as needed (Cañas, Novak, \& Reiska, 2015; Cañas, Reiska, \& Novak, 2016). C-Map application covers the following terms: "focus question, context, parking lots, crosslinks or grouping, hierarchy branching, and proposition" (Cañas et al., 2004; Cañas et al., 2016; Suprapto et al., 2018). Every concept was characterized by focus question that covers the concept map. The whole manifestation of a concept map is context. Coutinho (2014) defined "parking lots or concept are objects, events, situations or properties of things that designated by a label or symbol". The following are the main rules in the concept map (Cañas et al., 2004; Cañas et al., 2016; Suprapto et al., 2018):

1) "Concepts on a map can be represented as a hierarchical structure in which the more general, more inclusive concepts are at the top of the map";

2) "The specific and exclusive concepts are at the lower end of the map";

3) "Concept hierarchy is based upon the extent that concepts are present in assigned levels as designated by the instructor";

4) "Grouping at the ways concepts can be linked or joined together";

5) "Branching of concepts refers to the level of differentiation among concepts, that is, the extent the more specific concepts are connected to more general concepts";

6) "Proposition is relationships between concepts are represented by connecting word(s) and phrases written on the line joining any two concepts".

The display of C-Map application software is illustrated in Figure 1.

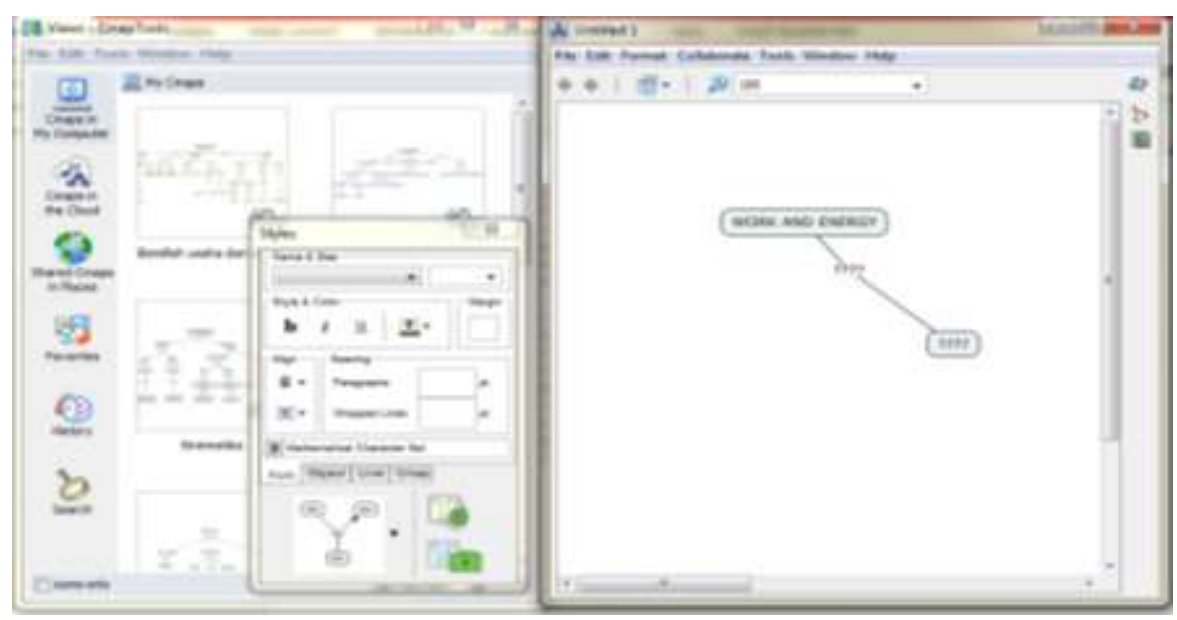

Figure 1

The display of C-Map application

\section{Assessment of the Quality of Concept Map}

Coutinho (2014) said that one of the biggest problems of the developing concept maps is the assessment process because map is prepared by the perception of individuals 
learning. In other words, there are no maps that $100 \%$ incorrect (or wrong). There are some assessment models of the concept map. In this study, researchers used the criteria evaluation of Suprapto et al. (2018). The criteria evaluation of concept map is shown in Figure 2.

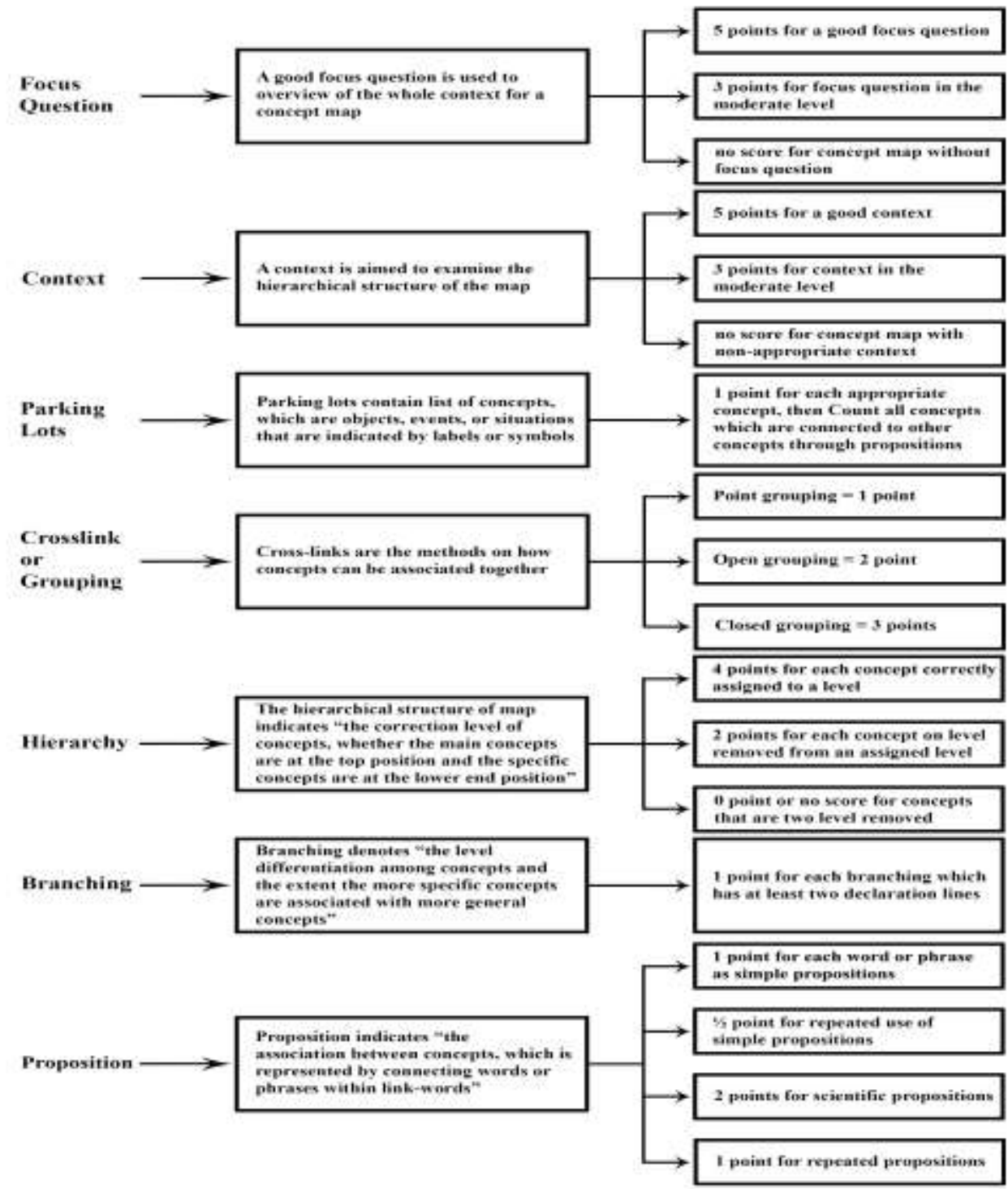

Figure 2

Criteria evaluation (rubrics) of concept map (Suprapto et al., 2018) 
Based on the introduction and the context and literature review, the research purposes of this study were simplified into twofold:

1) To analyze the students' understanding in work and energy matter after implementation of C-Map application.

2) To analyze the students' skills to make a concept map through C-Map Application.

\section{METHOD}

\section{Research Design}

The true experimental design was utilized in this research method. A randomized control group pre-test and post-test design was selected as the type of method. This study was designed for two groups, namely: the control group (CG) and the experimental group (EG) (Creswell, 2012; Llinas, J.G. Macias, F.S., \& Marquez, M. L. T. 2018).

Table 1

Randomized control group pre-test and post-test design

\begin{tabular}{llll}
\hline Group & Pre-test & Implementation & Post-test \\
\hline EG & $\mathrm{T}_{1}$ & $\mathrm{X}$ & $\mathrm{T}_{2}$ \\
\hline CG & $\mathrm{T}_{1}$ & - & $\mathrm{T}_{2}$ \\
\hline
\end{tabular}

Sample of this research is two groups of science group, in second semester of $10^{\text {th }}$ grade. EG was used implementation of C-Map application in the learning process. Meanwhile, the CG utilized traditional learning with a routine learning conducting in daily school lesson.

\section{Procedure}

This research focuses on students' understanding and skill to make concept map using C-Map application software. The study was begun by the developing learning materials involved syllabus, lesson plans, student' book, conceptual instrument test and students' worksheet. Before the implementation C-Map application in the learning process, students were given pretest to evaluate prior students' understanding in work and energy matter. After developing learning materials and evaluate students' understanding, it was followed by implementation of C-Map application in the learning process. The teacher guides students to make concept map through C-Map application in physics matter. Then, students create concept map in work and energy topic by C-Map application. After creating a concept map, the teacher teaches the students' how to assess concept map based on Suprapto's rubrics. The result of the concept map in work and energy matter was assessed by Suprapto's rubrics. The whole process of implementation the CMap application starting by the modeling by the teacher that is illustrated in Figure 3a, 3b, 3c, and 3d (Nurcahyani, \& Suprapto, 2019). 


\section{Instrument}

Conceptual instrument and students' worksheet implemented in this study had been developed by the second author. These instruments have been validated by two physics education experts and they have been checked the coefficient of agreement among experts. The evaluation aspect was content, construction, language and concept map. The results validation had confirmed that the conceptual instrument percentage was $86.36 \%$ in the very good category. The students' worksheet percentage was in $91.6 \%$ very good categories.

\section{Data Analysis}

A statistical descriptive analysis was used in this study. Independent t-test and normalized gain ( $\mathrm{N}$-gain) were used to analysis the data. Independent t-test was used to indicate the presence of effect implementation of C-Map application in the learning process. The average of normalized gain was utilized to decide the gained level of students' understanding of work and energy matter. Hake (1999) guided us to determine $\mathrm{N}$-gain as follows:

"N-gain $=($ post-test - pre-test $) /($ maximum score - pre-test score $) "$

Table 2

Gain Score Interpretation Criteria

\begin{tabular}{ll}
\hline Gain Score $(\mathrm{g})$ & Interpretation \\
\hline$(\mathrm{g})>0.7$ & High \\
\hline $0.7 \geq(\mathrm{g}) \geq 0.3$ & medium \\
\hline$(\mathrm{g})<0.3$ & low \\
\hline
\end{tabular}

The result of concept map in work and energy matter was assessed by Suprapto's et al. (2018) rubric. The rubric was used to evaluate students' skill to make a concept map through C-Map application. 


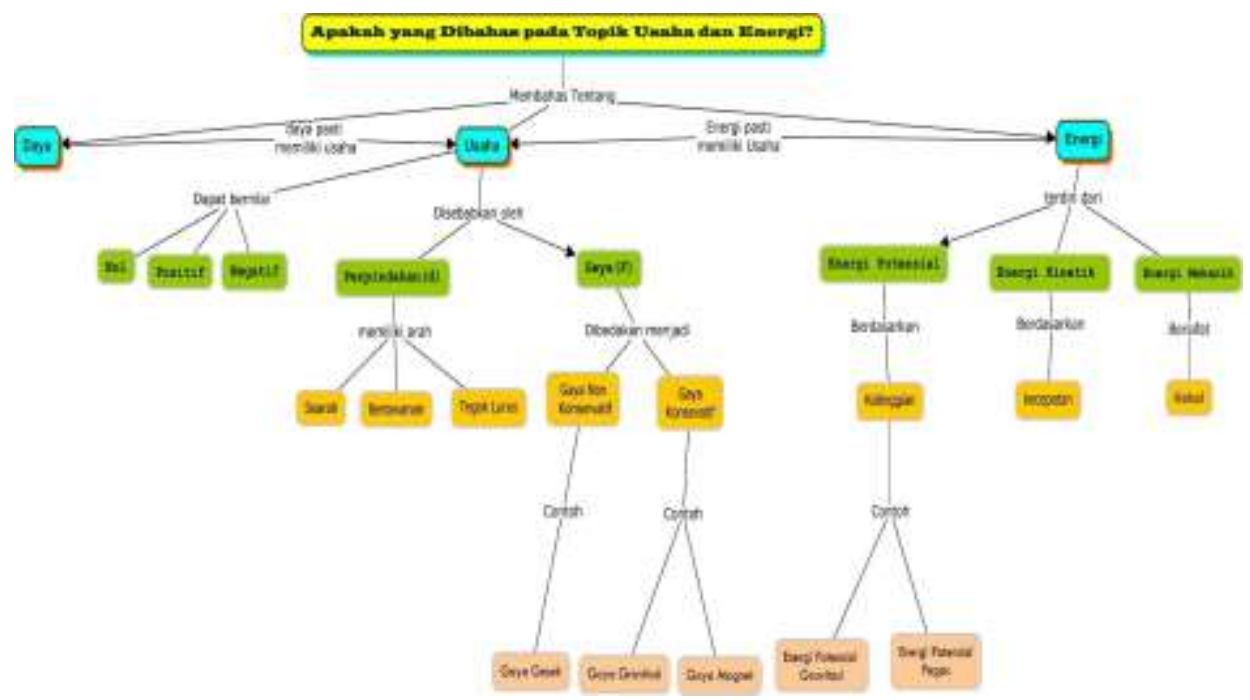

Figure $3 \mathrm{a}$

Modeling of concept map of work and energy created by teacher with C-Map application

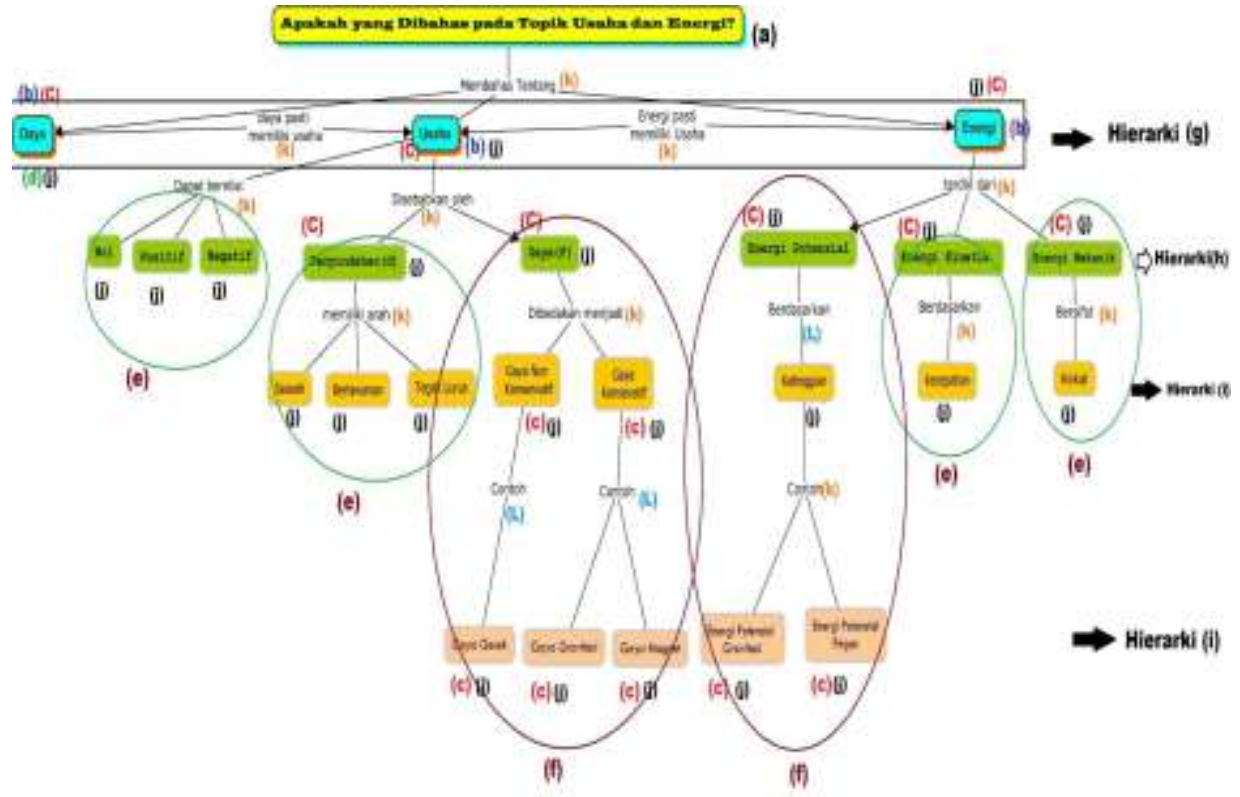

Figure $3 b$

Scoring process of concept map based on the rubrics in Figure 2 
Table 3

The results of evaluation of teachers' concept map about work and energy based on the rubrics

\begin{tabular}{llllll}
\hline No & Aspect & Symbol & Amount & Point & Total \\
\hline 1 & focus of the question & $\mathrm{a}$ & 1 & 5 & 5 \\
\hline 2 & context & $\mathrm{b}$ & 1 & 5 & 5 \\
\hline 3 & Parking lots & $\mathrm{c}$ & 15 & 1 & 15 \\
\hline 4 & Cross Links (Point Grouping) & $\mathrm{d}$ & 1 & 1 & 1 \\
\hline 5 & Cross Links (Open Grouping) & $\mathrm{e}$ & 4 & 2 & 8 \\
\hline 6 & Cross Links (Closed Grouping) & $\mathrm{f}$ & 2 & 3 & 6 \\
\hline 7 & Hierarchy (True concept at the same level) & $\mathrm{g}$ & 1 & 4 & 4 \\
\hline 8 & Hierarchy (There is one concept that is omitted & $\mathrm{h}$ & 1 & 2 & 2 \\
\hline 9 & Hierarchy (There are two or more concepts that & $\mathrm{i}$ & 2 & 0 & 0 \\
\hline 10 & Branching & $\mathrm{i}$ & 2 & \\
\hline 11 & Simple Proposition & $\mathrm{j}$ & 23 & 1 & 23 \\
\hline 12 & Repeated Proposition & $\mathrm{k}$ & 11 & 1 & 11 \\
\hline & Total & $\mathrm{l}$ & 3 & $1 / 2$ & 1.5 \\
\hline
\end{tabular}

\section{FINDINGS}

\section{Students' Understanding in Work and Energy Topics}

Students' understanding of work and energy obtained through multiple choice tests which consisting of twenty questions. Implementation of C-Map application in work and energy matter was conducted in experiment group. The result of data analysis was showed in that Table 4.

Table 4

Normality test

\begin{tabular}{|c|c|c|c|c|c|}
\hline \multirow{2}{*}{ Group } & \multirow[b]{2}{*}{$\alpha$} & \multirow{2}{*}{$d f$} & \multirow{2}{*}{$x_{t a b l e}^{2}$} & Pre-test & Post-test \\
\hline & & & & $x_{\text {result }}^{2}$ & $x_{\text {result }}^{2}$ \\
\hline $\begin{array}{l}\text { CG } \\
\text { EG }\end{array}$ & 0.05 & 5 & 11.07 & 0.0587 & 0.289 \\
\hline
\end{tabular}

According to Table 4 above, it showed that the result of normality $\left(x^{2}\right.$ result $)$ in pre-test and post-test is lower than $x_{\text {table }}^{2}$. By using significant interpretation $(\alpha)=0.05$, it can be concluded that $\mathrm{H}_{0}$ accepted, so the distribution of pre-test and post-test score was normal.

Table 5

Homogeneity test

\begin{tabular}{lllll}
\hline \multirow{2}{*}{ Group } & \multirow{2}{*}{$\boldsymbol{\alpha}$} & \multirow{2}{*}{$\boldsymbol{x}_{\text {table }}^{2}$} & Pre-test & Post-test \\
\cline { 4 - 5 } & \multirow{2}{*}{0.05} & \multirow{2}{*}{3.841} & $\boldsymbol{x}_{\text {result }}^{2}$ & $\boldsymbol{x}_{\text {result }}^{2}$ \\
\cline { 3 - 5 } CG & & 8.74 & 8.72 \\
\hline EG & & & 8.33 & 4.07 \\
\hline
\end{tabular}


According to Table 5 above, it indicated that the result of homogeneity $\left(x^{2}\right.$ result $)$ in pretest and post-test is lower than $x_{\text {table }}^{2}$. Using significant interpretation $(\alpha)=0.05$, it can be concluded that $\mathrm{H}_{0}$ accepted, so the distribution of pre-test and post-test score was homogeneous.

Table 6

Independent t-test (two-tailed)

\begin{tabular}{lllll}
\hline Test Group & Comparison Group & $t_{\text {result }}$ & $t_{\text {table }}$ & Conclusion \\
\hline EG & CG & 3.327 & 1.99 & $\mathrm{H}_{0}$ rejected \\
\hline
\end{tabular}

The result of independent t-test (two-tailed) was 3.327. In which the hypotheses of independent t-test (two-tailed) resulted students' understanding in EG equal with $\mathrm{CG}$ $\left(\mathrm{H}_{0}\right)$ and result students' understanding in EG different with $\mathrm{CG}\left(\mathrm{H}_{1}\right)$. Based on Table 6, it revealed that the $t_{\text {result }}$ was larger than $t_{\text {table }}$, so it can be concluded that $\mathrm{H}_{0}$ was rejected and $\mathrm{H}_{1}$ was accepted.

Table 7

Independent t-test (one-tailed)

\begin{tabular}{lllll}
\hline Test Group & Comparison Group & $t_{\text {result }}$ & $t_{\text {table }}$ & Conclusion \\
\hline EG & CG & 3.327 & 1.99 & $\mathrm{H}_{0}$ rejected \\
\hline
\end{tabular}

The result of independent t-test (two-tailed) was 3.327. Meanwhile, the hypotheses of independent t-test (two-tailed) resulted students' understanding in EG equal with $\mathrm{CG}$ $\left(\mathrm{H}_{0}\right)$ and the result students' understanding in EG more significant than $\mathrm{CG}\left(\mathrm{H}_{1}\right)$. Based on Table 7, it presented that the $t_{\text {result }}$ was larger than $t_{\text {table }}$, so it can be concluded that $\mathrm{H}_{0}$ was rejected and $\mathrm{H}_{1}$ was accepted.

Table 8

Analysis of gain-score

\begin{tabular}{lll}
\hline Group & $N$-gain & Category \\
\hline EG & 0.39 & Medium \\
\hline CG & 0.27 & Low \\
\hline
\end{tabular}

Analysis of students' understanding was measured by the instrument test of work and energy. Pre-test was used to measure prior to students' understanding in work and energy matter. Post-test was used to measure students' understanding in work and energy after implementation of C-Map application in the learning process. Based on Table 8, it indicated that the result of $\mathrm{N}$-gain in $\mathrm{EG}$ was 0.39 in the medium category and CG was 0.26 in the low category.

\section{Students' Skill to Make Concept Map through C-Map Application}

Students' skill to make a concept map was assessed by Suprapto's rubric. There were six students' groups (SG) in a group. Every group made a concept map in work energy matter through C-Map application. The score students' skill to make a concept map is shown in Table 9. 
Table 9

The result of students' skill to make concept map

\begin{tabular}{ll}
\hline Students' Group (SG) & Score \\
\hline SG 1 & 84.47 \\
\hline SG 2 & 74.53 \\
\hline SG 3 & 72.67 \\
\hline SG 4 & 93.16 \\
\hline SG 5 & 87.57 \\
\hline SG 6 & 75.77 \\
\hline Average & 83.16 \\
\hline
\end{tabular}

Based on Table 9, we can see the average of students' skill score to make concept map was 83.16 in very good category. An example of concept map was made by students' in work and energy matter [English version] was showed in Figure 4. Meanwhile, the original version [in Indonesia] is illustrated in Figure 5.

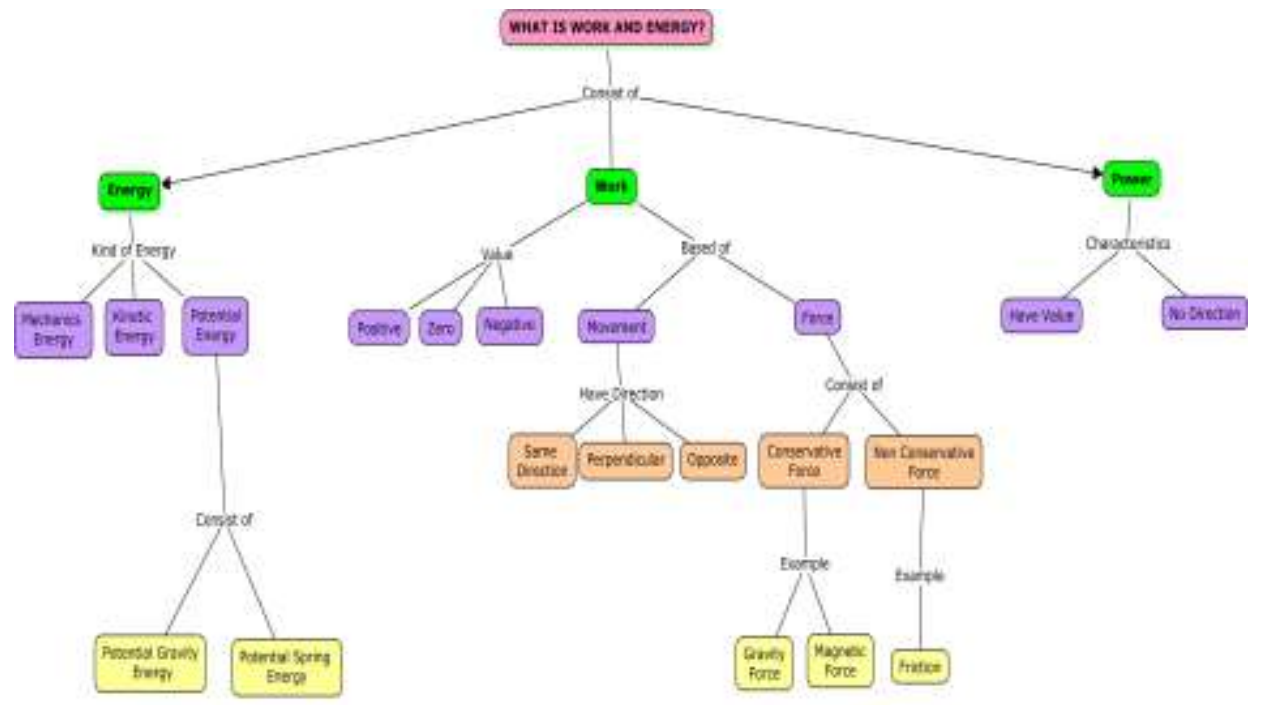

Figure 4

An example concept map in work and energy matter [English version] 


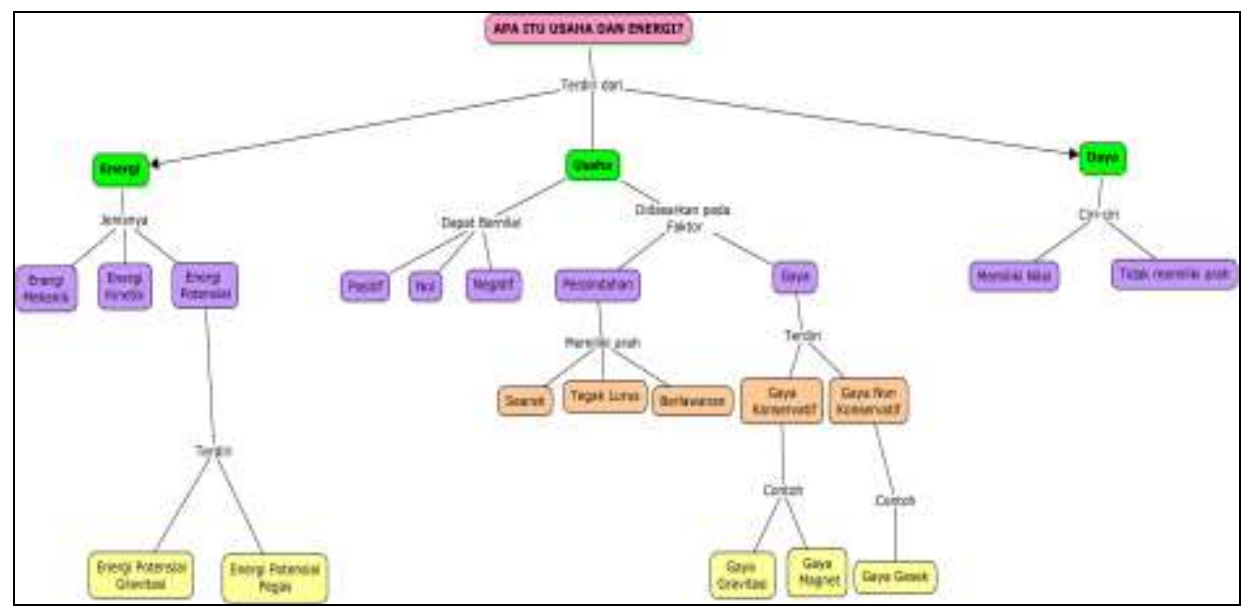

Figure 5

Real result concept map in work and energy created by students [Indonesian version]

Based on Figure 4 and Figure 5, a simple analysis could be dedicated to the simple concept map created by a student as follow:

a. The concept map is not complete, however the student has able to perform the component of map, such as: context, parking lots, proposition, grouping, branching, and hierarchy of concepts.

b. The specific of concept map was developed is starting by focus questioning. The role of focus question is guiding the students' learning (Suprapto, 2019).

c. Student classify the discussion of work and energy matter into three parts: energy, work, and power

d. The attribute of energy includes mechanics, kinetic, and potential energy; then for work is separated based on its value and quantities influenced

e. The parking lots of the concept of power are less than energy and works. It means student more understand these concepts than power.

\section{DISCUSSION}

The implementation of C-Map application was utilized to improve students' understanding of work and energy. Pre-test and post-test were used to evaluate the students' understanding of these two concepts. Pre-test was piloted to show students' prior understanding. Post-test was conducted to show students' understanding of work and energy matter after implementation of C-Map application in the learning process. Independent t-test showed students' understanding result. Independent t-test with twotailed was used to find out whether there is a difference of the result students' understanding between the two groups. Table 6 showed the conclusion, $\mathrm{H}_{0}$ was rejected and $\mathrm{H}_{1}$ was accepted, so it indicated that students' understanding of work and energy 
after implementation of C-map application of experiment group different from control group. Meanwhile, independent t-test with one-tailed was used to determine which group more significant after implementation of C-Map application in work and energy matter. Table 7 revealed the conclusion, $\mathrm{H}_{0}$ was rejected and $\mathrm{H}_{1}$ was accepted, so it pointed out that students' understanding in work and energy matter of experiment group more significant than control group.

According to the Table 8 , an analysis of gain score showed that there was a different result of gain score between experiment group and control group. Gain score of experiment group was 0.39 and control group was 0.26 . Based on the $\mathrm{N}$-gain result, there is a difference between students' understanding of experiment group and control group. N-gain result indicated that the quality improvement of students' understanding in work and energy matter after implementation C-Map application were categorized as medium level in experiment group and low level in control group. Implementation of CMap application in work and energy improved students' understanding, however, the improvement of experiment group higher than control group. This finding confirmed the study of Suprapto et al. (2018), who underlined that "making concept map through CMap application can investigate the level understanding of matter and concept map one of indicator physics understanding". Moreover, the finding has also supported the premise: "the implementation of concept map as a consolidation phase can improve student concept comprehension about environmental pollution" (Nugroho et al., 2017).

According to Table 7, it showed that the average of students' skill to make concept map through C-Map application was $81.36 \%$ in very good category. Implementation of CMap application in work and energy provided good experiences and impressions for students. Students' made a concept map in a group, which every group made concept map in work and energy matter at the end of learning. The teacher has guided and trained on how to make concept maps using C-Map application. In addition, the teacher explained the components used as the assessment rubric in the concept map and taught how to assess concept maps according to the rubric described by Suprapto et al. (2018). The component of the concept map consisted of "focus question, context, parking lots, crosslinks, hierarchy, branching, and proposition" (Suprapto et al., 2018). Every concept map has focus question, it will be constructed into other concepts from a general concept to a specific concept. However, this research has also found a limitation: in constructing a concept map, there were still several groups who were still confused in distinguishing concepts or non-concepts.

In the training phase of creating concept maps using C-Map application that were trained by the teacher, she explained and gave examples of which ones include concepts or non-concepts. Through creating concept maps, students can connect between one concept and another concept. Additionally, students also know the hierarchy of a concept. Concept map was measuring tool for understanding students' understanding and knowing the relationship (correlation) between one concept and another concept, besides, making concept maps can reduce the level of participant misconception student (Nair \& Narayanasamy, 2017). Their research underlined the implementation of concept map relating to the concept meaningful learning and utilization of concept map. In 
making concept maps using C-Map application, students' still need guidance or direction from the teacher because students were only familiar with the application to create concept maps. Before this treatment, especially in the previous physics learning, students have never made concept maps through C-Map application in learning activities. By using this application, students find it easier to arrange and change the layout, addition and subtraction of the concepts they learned. Another case, if students used classic method they have to redraw and redesign the concept map that will be made if there are things wrong or need to be changed, this is requires a much time. So, if students using the C-Map application, they can save the time and more efficient. Additionally, students' skill in developing concept map of work and energy matter by using C-Map application optimize their multiple intelligence especially visual, logical mathematics, linguistic intelligence (Suprapto, Liu, \& Ku, 2017).

\section{CONCLUSION}

The implementation of C-Map Application in work and energy work and energy matter improves students' understanding. Students' understanding performed that experiment group higher than the control group, which gain score in experiment group was 0.39 in the medium category and control group was 0.26 in the low category. Students' skill to make concept maps through C-Map application software in work and energy matter reached the percentage of $81.36 \%$ in very good category. Students' was constructed the concept from general concept to specific concept and students connect the concept to another concept. C-Map application guide students to control the hierarchical structure concept of work and energy, by constructing concept from focus question to see the relations of concept to another concept.

\section{ACKNOWLEDGEMENT}

The authors would like to thank students and teacher from a public school in Gresik regency. Additionally, we would like also to thank the developer of C-Map software, especially IHMC, J Novak and teams.

\section{REFERENCES}

Akınoğlu, O. (2017). Pre-service teachers' metaphorical perceptions regarding the concept of curriculum. International Journal of Instruction, 10(2), 263-278. https://doi.org/10.12973/iji.2017.10217a

Cañas, A. J., Hill, G., Carff, R., Suri, N., Lott, J., \& Eskridge, T. (2004). C-map application: A knowledge modeling and sharing environment. In A J Cañas, J D Novak and F M González (Eds.), Concept maps: Theory, methodology, technology. Proc. of the first Int. Conf. on concept mapping (Vol. I, pp. 125-133). Pamplona, Spain: Universidad Pública de Navarra.

Cañas, A. J., Novak, J. D. \& Reiska, P. (2015). From representing to modelling knowledge: Proposing a two-step training for excellence in concept mapping. Knowledge Management \& E-Learning: An International Journal (KM\&EL). 7(1). 6-19. 
Cañas, A. J., Reiska, P., \& Novak, J. D. (2016). Is my concept map large enough? Innovating with Concept Mapping (pp. 128-143). Springer.

Chu, S. K. W., Reynolds, R. B., Tavares, N.J., Notari, M., \& Lee, T. W. Y. (2017). $21^{s t}$ century skills development through inquiry-based learning. Singapore: Springer Science+Busisness Media. https://doi.org/10.1007/978-981-10-24811-8

Coutinho, E. (2014). Concept maps: Evaluation models for educators. Journal of Business and Management Sciences, 2(5), 111-117. Retrieved from DOI: $10.12691 / \mathrm{jbms}-2-5-4$

Creswell, J. W. (2012). Educational research: Planning, conducting, and evaluating quantitative and qualitative research (4th Ed.). Boston, MA: Pearson.

Hake, R. (1999). Analyzing changel gain scores. (online), (httpp://www.Physics.indiana.edu/ sdi/AnalyzingChang-Gain.pdf,

Gourlay, R. (2017). Learning about A level physics students' understandings of particle physics using concept mapping. Journal of Physics: Conference Series, 52, 1-9. https://doi.org/10.1088/1361-6552/52/1/014001

Lestari, N. A., Suprapto, N., Deta, U. A., \& Yantidewi, M. (2018). Implementation of multimodel active learning to improve basic teaching skills of pre-service physics teachers. Journal of Physics: Conference Series, 1108 (012119), 1-5. https://doi.org/10.1088/1742-6596/1108/1/012119

Llinas, J. G. Macias, F. S., \& Marquez, M. L. T. (2018). The use of concept maps as an assesment tool in physics groupes: Can one use concept maps for quantitative evaluations? Researh in Education Journal. 48. https://doi.org/10.1007/s11165-0189753-4

Nair, S. M., \& Narayanasamy, M. (2017). The effect of utilising the concept map in teaching history. International Journal of Instruction, 10(3), 109-126. https://doi.org/10.12973/iji.2017.1038a

Novak, J. D., \& Gowin, D. B. (2012). Learning how to learn. New York: Cornell University.

Nugroho, O. F., Chandra, D. T., \& Sanjaya, Y. (2017). The use of concept map as a consolidation phase based STAD to enhance student's comprehension about environmental pollution. Journal of Physics: Conference Series, 812 (012071), 1-5. https://doi.org/10.1088/1742-6596/812/1/012071

Nurcahyani, D., \& Suprapto, N. (2019). Students' responses toward the implementation of C-map application in physics learning. Jurnal Inovasi Pendidikan Fisika, 8(2), 569571.

Santrock, J. W. (2014). Psikologi Pendidikan Edisi 5 Buku 2. Terjemahan Harya Bimasena. Jakarta: Salemba Humanika. 
Sarker, P. K. (2015). Use of concept maps for problem-solving in engineering. Global Journal of Engineering Education. 17 (1). 29-33.

Sukma, B., Supriyono Koes H., \& Kusairi, S. (2016). Identifikasi penguasaan konsep siswa pada materi usaha dan energi. Prosiding Semnas Pendidikan IPA Pascasarjana UM. 1. 208-212.

Suprapto, N. (2019). Development and Validation of Students' Perception on Learning by Questioning Scale in Physics. International Journal of Instruction, 12(2), 243-258.

Suprapto, N., Chang, T.-S., \& Ku, C.-H. (2017). Conception of learning physics and self-efficacy among Indonesian university students. Journal of Baltic Science Education, 16(1), 7-19.

Suprapto, N., Liu, W.-Y., \& Ku, C.-H. (2017). The implementation of multiple intelligence in (Science) classroom: From empirical into critical | [Daugialypio intelekto teorijos taikymas (Tiksliujų mokslų) pamokose: nuo empirinio iki kritinio požiūrio]. Pedagogika, 126(2), 214-227.

Suprapto, N., Suliyanah, Prahani, B. K., Jauhariyah, M.N.R., \& Admoko, S. (2018). Exploring physics concept among novice teachers through CMAP tools. Journal of Physics Conference Series, 997, 1-7. https://doi.org/10.1088/1742-6596/1157/3/032023

Usta, N. D., \& Ültay, N. (2016). Prospective chemistry teachers' abilities of creating concept map: Hydrocarbon example. Journal of Baltic Science Education, 15 (1). 5867. 